\title{
ANALISIS PERAMALAN PENJUALAN DAN PENGGUNAAN METODE LINEAR PROGRAMMING DAN DECISION TREE GUNA MENGOPTIMALKAN KEUNTUNGAN PADA PT PRIMAJAYA PANTES GARMENT
}

\author{
Inti Sariani Jianta Djie \\ PT Anugerah Ajita Sukses Bersama \\ Jln. Semanan Raya No.27, Daan Mogot Km.16, Kalideres, Jakarta Barat \\ inti.djie@gmail.com
}

\begin{abstract}
Primajaya Pantes Garment is a company that runs its business in garment sector. However, due to various numbers of requests each month, the company is difficult to determine the amount of production per month that is appropriate to maximize profits. The purpose of this study is to determine the appropriate forecasting method that can be used as a reference to determine the amount of production in the next period and to find a combination of products to maximize profits. Research used forecasting methods, including naive method, moving averages, weighted moving averages, exponential smoothing, exponential smoothing with trend, and linear regression. In addition, this study also used Linear Programming method with Simplex method to determine the best combination of products for the company and to choose a decision using a decision tree to determine which alternative should be done by the company. Results of this study found that the linear regression method is the most appropriate method in determining the forecast demand in the next period. While in the Linear Programming method, constraints used were the constraints of raw materials, labor hours, and limited demand for the product. The result of the decision tree is to increase production capacity.
\end{abstract}

Keywords: linear programming, forecasting, decision tree, linear regression

\begin{abstract}
ABSTRAK
PT Primajaya Pantes Garment merupakan perusahaan yang bergerak dalam bidang pakaian jadi. Karena jumlah permintaan setiap bulan bervariasi, perusahaan sulit menentukan jumlah produksi setiap bulan secara tepat untuk memaksimalkan laba perusahaan. Tujuan penelitian ini adalah untuk menentukan metode peramalan yang tepat yang dapat digunakan sebagai acuan untuk menentukan jumlah produksi pada periode berikutnya dan mengetahui kombinasi produk untuk memaksimalkan laba. Metode yang digunakan dalam penelitian ini adalah metode peramalan, di antaranya naive method, moving averages, weighted moving averages, exponential smoothing, exponential smoothing with trend, dan regresi linear. Selain itu, dalam penelitian ini juga digunakan metode Linear Programming dengan model simpleks untuk menentukan kombinasi produk terbaik bagi perusahaan dan pengambilan keputusan menggunakan pohon keputusan untuk menentukan alternatif mana yang sebaiknya dilakukan oleh perusahaan. Dari hasil penelitian ini didapatkan bahwa metode regresi linear merupakan metode yang paling tepat dalam menentukan peramalan permintaan pada periode berikutnya. Sedangkan dalam metode Linear Programming, kendala-kendala yang digunakan adalah kendala bahan baku, jam kerja tenaga kerja, dan keterbatasan permintaan produk. Hasil dari pengambilan keputusan dengan menggunakan pohon keputusan adalah meningkatkan kapasitas produksi.
\end{abstract}

Kata kunci: linear programming, forecasting, decision tree, linear regression 


\section{PENDAHULUAN}

Perkembangan ekonomi di Indonesia pada saat ini berkembang cukup pesat. Banyak industri tumbuh berkembang, sehingga mengakibatkan pesaing makin banyak di dalam industri, misalnya pada industri pakaian jadi. Seiring dengan perkembangan zaman dan perubahan budaya, minat konsumen terhadap fashion makin tinggi. Hal ini menyebabkan permintaan konsumen terhadap pakaian jadi juga ikut berubah sesuai dengan fashion yang sedang tren saat ini.

Permintaan konsumen yang tidak menentu seiring dengan pergantian tren fashion yang berubah dengan cepat bersamaan dengan perkembangan zaman berpengaruh pada penjualan perusahaan. Makin tinggi permintaan konsumen, makin tinggi pula penjualan yang dilakukan oleh perusahaan. Hal ini membuat persaingan di industri pakaian menjadi makin ketat karena kompetitor sangat mudah untuk masuk dan bersaing dalam industri. Akibatnya, industri manufaktur makro dan sedang pakaian jadi mengalami penurunan produksi sebesar 16,95\% pada triwulan I tahun 2012.

Melihat kondisi pertumbuhan industri yang meningkat cukup besar membuat perusahaan yang berkecimpung dalam industri pakaian jadi harus mempersiapkan strategi yang matang agar dapat bersaing dengan kompetitornya. Karena berdasarkan data tersebut, pertumbuhan industri berdampak cukup besar terhadap penurunan produksi industry. Artinya, makin banyaknya perusahaan yang masuk ke dalam industri secara tidak langsung akan memengaruhi produksi perusahaan dalam industri pakaian jadi. Menurunnya produksi menandakan bahwa terjadi penurunan penjualan dalam perusahaan.

Untuk mengantisipasi hal tersebut, perusahaan perlu melakukan peramalan penjualan. Peramalan penjualan dapat digunakan bagi perusahaan untuk mengantisipasi hal-hal yang akan datang. Jika perusahaan salah melakukan peramalan penjualan, bisa terjadi hal-hal yang tidak diinginkan. Misalnya, perusahaan tidak bisa memenuhi permintaan konsumen yang tiba-tiba meninggi. Atau malahan, permintaan konsumen tidak sesuai dengan perkiraan perusahaan sehingga barang yang telah diproduksi tidak laku terjual. Dengan kata lain, perusahaan mengalami kelebihan produksi. Hal ini tentu saja dapat mendatangkan kerugian bagi perusahaan.

Meskipun begitu, selain melakukan peramalan penjualan, perusahaan juga dapat menerapkan metode linear programming untuk mengoptimalkan keuntungan perusahaan. Dengan menggunakan metode tersebut, perusahaan dapat mengetahui jenis produk mana yang akan diproduksi dalam jumlah tertentu untuk memaksimalkan keuntungan. Selain itu, perusahaan juga dapat menggunakan metode analisis pohon keputusan dalam menentukan alternatif mana yang dapat dilakukan oleh perusahaan, apakah dengan mengurangi jumlah bahan baku atau meningkatkan kapasitas produksi. Dengan menggunakan metode tersebut, perusahaan dapat memilih alternatif mana yang dapat mengoptimalkan laba perusahaan.

PT Primajaya Pantes Garment merupakan perusahaan yang bergerak dalam bidang industri pakaian jadi. Target pasar mereka adalah kalangan menengah ke atas dan mempunyai gerai-gerai tersendiri di beberapa mal di kota Jakarta. Produk-produk perusahaan tersebut sudah cukup bervariasi, mulai dari pakaian anak-anak hingga dewasa, untuk pria maupun wanita. Akan tetapi, perusahaan mengalami permasalahan, yaitu permintaan produk yang bervariasi tiap bulannya sehingga perusahaan sulit menentukan berapa jumlah produksi yang tepat sehingga terjadi kesulitan dalam memproyeksikan laba perusahaan. Oleh karena itu, perusahaan membutuhkan peramalan penjualan yang tepat ditunjang dengan penggunaan metode linear programming serta decision tree agar dapat memecahkan masalah yang dihadapi oleh perusahaan. Berdasarkan hal tersebut, penelitian ini dibuat dengan topic analisis peramalan penjualan dan penggunaan metode linear programming dan decision tree guna mengoptimalkan keuntungan pada PT Primajaya Pantes Garment. 
Perumusan masalah dalam penelitian adalah sebagai berikut. Pertama, metode peramalan manakah yang paling tepat untuk diterapkan PT Primajaya Pantes Garment. Kedua, berapa keuntungan optimal yang dapat diperoleh PT Primajaya Pantes Garment. Ketiga, alternatif apakah yang dapat dipilih PT Primajaya Pantes Garment untuk memaksimalkan laba. Sementara tujuan dari penelitian ini adalah sebagai berikut. Pertama, untuk mengetahui metode peramalan yang paling tepat untuk diterapkan oleh PT Primajaya Pantes Garment. Kedua, untuk mengetahui keuntungan optimal yang dapat diperoleh PT Primajaya Pantes Garment. Ketiga, untuk mengetahui alternatif yang dapat dipilih oleh PT. Primajaya Pantes Garment untuk memaksimalkan laba. Manfaat penelitian ini adalah untuk mengetahui metode peramalan yang paling tepat untuk digunakan perusahaan sehingga perusahaan dapat memperkirakan target penjualan yang ingin dicapai serta dapat menentukan kombinasi produk yang paling tepat untuk memaksimalkan keuntungan perusahaan.

\section{Tinjauan Pustaka}

\section{Peramalan}

Menurut Murahartawaty (2009), peramalan (forecasting) merupakan bagian vital bagi setiap organisasi bisnis dan untuk setiap pengambilan keputusan manajemen yang sangat signifikan. Peramalan menjadi dasar bagi perencanaan jangka panjang perusahaan. Menurut Hasibuan (2011), metode peramalan adalah suatu cara memperkirakan atau mengestimasi secara kuantitatif maupun kualitatif apa yang terjadi pada masa depan berdasarkan data yang relevan pada masa lalu.

Lebih lanjut, model deret waktu, menurut Heizer dan Render (2009), membuat prediksi dengan dengan asumsi bahwa masa depan merupakan fungsi dari masa lalu. Kemudian menurut Fariza (2007), suatu deret berkala (time series) merupakan suatu himpunan observasi, dengan variabel yang digunakan diukur dalam urutan periode waktu, misalnya tahunan, bulanan, triwulanan, dan sebagainya.

\section{Linear Programming}

Berdasarkan Murugan dan Manivel (2009), linear programming merupakan solusi yang cocok untuk digunakan oleh perusahaan multiproduk karena dengan memperkirakan berbagai kombinasi produk, perusahaan dapat memaksimalkan keuntungan serta memperkirakan jumlah produksi yang tepat. Namun dalam menerapkan linear programming diperlukan pengetahuan mengenai kombinasi produk yang tepat, target pasar, serta jumlah permintaan terhadap produk itu sendiri. Menurut Dimyati dan Dimyati (2006), linear programming menggunakan model matematis untuk menjelaskan persoalan yang dihadapinya.

Sementara Mulyono (2007), metode simpleks menyelesaikan masalah linear programming melalui perhitungan-ulang (iteration). Langkah-langkah perhitungan yang sama diulang berkali-kali sebelum solusi optimum dicapai.

\section{Pohon Keputusan}

Menurut Nugroho (2002), pohon keputusan adalah model prediksi menggunakan struktur pohon atau struktur berhierarki. Konsep dari pohon keputusan adalah mengubah data menjadi pohon keputusan dan aturan-aturan keputusan.

\section{METODE}

Penelitian dilakukan dengan menggunakan data penjualan dari PT Primajaya Pantes Garment periode Januari 2012 - Desember 2012. 
Tabel 1 Data Penjualan per Produk Tahun 2012

\begin{tabular}{cccc}
\hline Bulan & Polo Shirt Pria & Polo Shirt Wanita & Polo Shirt Anak-anak \\
\hline Januari & 1113 & 620 & 317 \\
Februari & 1008 & 548 & 274 \\
Maret & 996 & 541 & 271 \\
April & 1028 & 559 & 279 \\
Mei & 1025 & 557 & 305 \\
Juni & 1017 & 610 & 299 \\
Juli & 1099 & 598 & 267 \\
Agustus & 1121 & 620 & 315 \\
September & 1079 & 535 & 287 \\
Oktober & 1057 & 540 & 267 \\
November & 983 & 587 & 288 \\
Desember & 1093 & 597 & 316 \\
\hline
\end{tabular}

Sumber: PT Primajaya Pantes Garment (2012)

Berikut ini adalah data yang digunakan dalam metode Linear Programming:

- Variabel Keputusan

$$
\begin{aligned}
& \mathrm{X}_{1}=\text { Polo shirt } \text { pria } \\
& \mathrm{X}_{2}=\text { Polo shirt } \text { wanita } \\
& \mathrm{X}_{3}=\text { Polo shirt } \text { anak-anak }
\end{aligned}
$$

- Fungsi Kendala

Kendala bahan baku kain:

$0,9463 \mathrm{X} 1+0,6927 \mathrm{X} 2+0,1985 \mathrm{X} 3 \leq 2.200$

Kendala jam kerja tenaga kerja:

$0,8333 \mathrm{X} 1+0,7833 \mathrm{X} 2+0,6667 \mathrm{X} 3 \leq 5.760$

Kendala peramalan permintaan produk:

$\mathrm{X} 1 \leq 1065$

$\mathrm{X} 2 \leq 579$

$\mathrm{X} 3 \leq 293$

- Fungsi Tujuan

$\mathrm{Zmax}=98.700 \mathrm{X}_{1}+71.700 \mathrm{X}_{2}+35.700 \mathrm{X}_{3}$

Tabel 2 Tabel Alternatif bagi PT Primajaya Pantes Garment

\begin{tabular}{lccc}
\multicolumn{1}{c}{ Alternatif } & $\begin{array}{c}\text { Kondisi Ekonomi } \\
\text { Baik (A1) }\end{array}$ & $\begin{array}{c}\text { Kondisi Ekonomi } \\
\text { Buruk (A2) }\end{array}$ & Jumlah \\
\hline $\begin{array}{l}\text { Mengurangi jumlah bahan } \\
\text { baku (B1) }\end{array}$ & 158.000 .000 & 137.000 .000 & 295.000 .000 \\
$\begin{array}{l}\text { Meningkatkan kapasitas } \\
\text { produksi (B2) }\end{array}$ & 164.000 .000 & 129.000 .000 & 293.000 .000 \\
\hline \multicolumn{1}{c}{ Jumlah } & 322.000 .000 & 266.000 .000 & 588.000 .000 \\
\hline
\end{tabular}

Sumber: PT Primajaya Pantes Garment (2013)

Yang pertama dilakukan adalah melakukan peramalan penjualan untuk periode berikutnya menggunakan 6 metode peramalan, kemudian dilakukan pengujian tingkat kesalahan menggunakan metode MAD dan MSE. Selanjutnya, digunakan metode Linear Programming untuk mengetahui keuntungan maksimal yang dapat dicapai perusahaan dan menggunakan pohon keputusan untuk pemilihan alternatif terbaik bagi perusahaan. 


\section{HASIL DAN PEMBAHASAN}

PT Primajaya Pantes Garment mempunyai tiga produk utama, yaitu polo shirt, celana jins, dan kemeja. Dalam produksinya, celana jins dan kemeja menggunakan tenaga outsorcing, sedangkan untuk polo shirt diproduksi sendiri oleh perusahaan. Oleh karena itu, penelitian memutuskan untuk menggunakan produk polo shirt karena dalam pengolahan data menggunakan Linear Programming menggunakan kendala bahan baku sebagai salah satu fungsi kendalanya. Produk polo shirt terbagi dalam 3 jenis, yaitu polo shirt pria, wanita, dan anak-anak.

Hasil perbandingan peramalan menggunakan 6 metode peramalan adalah sebagai berikut.

Tabel 3 Perhitungan Peramalan Penjualan Polo Shirt Pria

\begin{tabular}{llll}
\hline \multirow{2}{*}{ Metode } & \multicolumn{3}{c}{ Manual } \\
\cline { 2 - 4 } & \multicolumn{1}{c}{ Next Period } & \multicolumn{1}{c}{ MAD } & \multicolumn{1}{c}{ MSE } \\
\hline Naive Method & 1093 & 46,5455 & 3572,545 \\
Moving Averages & 1044,333 & 41,5926 & 2970,4086 \\
Weighted Moving Averages & 1052,8 & 41,4111 & 2782,2589 \\
Exponential Smoothing & 1058,501 & 50,6716 & 3578,2176 \\
Exponential Smoothing with Trend & 1050,7327 & 45,6255 & 3391,9262 \\
\hline Regresi Linear & \multicolumn{4}{c}{$\mathbf{1 0 6 5 , 3 7 8 9}$} & $\mathbf{3 9 , 5 8 8 5}$ & $\mathbf{2 0 7 0 , 2 0 0 7}$ \\
\hline \multicolumn{4}{c}{ Sumber: Diolah Penulis (2013) }
\end{tabular}

Tabel 4 Perhitungan Peramalan Penjualan Polo Shirt Wanita

\begin{tabular}{llll}
\hline \multirow{2}{*}{ Metode } & \multicolumn{3}{c}{ Manual } \\
\cline { 2 - 4 } & Next Period & \multicolumn{1}{c}{ MAD } & \multicolumn{1}{c}{ MSE } \\
\hline Naive Method & 597 & 30,2727 & 1687 \\
Moving Averages & 574,6667 & 34,8889 & 1648,7161 \\
Weighted Moving Averages & 582,6 & 30,9444 & 1467,574 \\
Exponential Smoothing & 580,0233 & 36,7352 & 1688,1960 \\
Exponential Smoothing with Trend & 572,1639 & 38,9075 & 1904,5978 \\
\hline Regresi Linear & $\mathbf{5 7 9 , 3 6 3 8}$ & $\mathbf{2 7 , 5 1 8 2}$ & $\mathbf{9 3 1 , 7 8 2 6}$ \\
\hline
\end{tabular}

Sumber: Diolah Penulis (2013)

Tabel 5 Perhitungan Peramalan Penjualan Polo Shirt Anak-anak

\begin{tabular}{llll}
\hline \multicolumn{1}{c}{ Metode } & \multicolumn{3}{c}{ Manual } \\
\cline { 2 - 4 } & Next Period & MAD & \multicolumn{1}{c}{ MSE } \\
\hline Naive Method & 316 & 23,9091 & 761 \\
Moving Averages & 290,3333 & 18,963 & 483,3951 \\
Weighted Moving Averages & 297,8 & 19,4889 & 522,4822 \\
Exponential Smoothing & 294,9976 & 21,3853 & 607,9221 \\
Exponential Smoothing with Trend & 290,2384 & 22,3627 & 669,8149 \\
\hline Regresi Linear & $\mathbf{2 9 3 , 2 5 7 2}$ & $\mathbf{1 6 , 6 8 9 2}$ & $\mathbf{3 4 2 , 9 6 6 7}$ \\
\hline
\end{tabular}

Sumber: Diolah Penulis (2013) 
Catatan: angka yang dicetak tebal menunjukkan hasil peramalan dengan MAD dan MSE terkecil. Berdasarkan tabel, semua hasil peramalan menunjukkan bahwa metode regresi linear memiliki angka MAD dan MSE yang terkecil. Oleh karena itu, hasil peramalan dengan metode regresi linear yang selanjutnya akan diolah menggunakan metode Linear Programming (Tabel 6).

Tabel 6 Hasil Akhir dari Perhitungan Menggunakan Metode Linear Programming

\begin{tabular}{|c|c|c|c|c|c|c|c|c|c|c|}
\hline \multirow{2}{*}{$\begin{array}{c}\mathbf{C j} \\
\text { Iterasi } 4 \\
\end{array}$} & \multirow{2}{*}{ Basis } & 98700 & 71700 & 35700 & $\mathbf{0}$ & $\mathbf{0}$ & $\mathbf{0}$ & $\mathbf{0}$ & $\mathbf{0}$ & \multirow{2}{*}{ Quantity } \\
\hline & & $\mathrm{X}_{1}$ & $\mathbf{X}_{2}$ & $\mathbf{X}_{3}$ & $S_{1}$ & $\mathbf{S}_{2}$ & $\mathbf{S}_{3}$ & $S_{4}$ & $S_{5}$ & \\
\hline & $\mathrm{Z}$ & 0 & 0 & 0 & 0 & 0 & 98700 & 71700 & 35700 & 157089900 \\
\hline 0 & $\mathrm{~S}_{1}$ & 0 & 0 & 0 & 0 & 0 & $-0,9463$ & $-0,6927$ & $-0,2985$ & 703,6567 \\
\hline 0 & $\mathrm{~S}_{2}$ & 0 & 0 & 0 & 0 & 1 & $-0,8333$ & $-0,7833$ & $-0,6667$ & 4223,6617 \\
\hline 98700 & $\mathrm{X}_{1}$ & 1 & 0 & 0 & 0 & 0 & 1 & 0 & 0 & 1065 \\
\hline 71700 & $\mathrm{X}_{2}$ & 0 & 1 & 0 & 0 & 0 & 0 & 1 & 0 & 579 \\
\hline \multirow[t]{3}{*}{35700} & $X_{3}$ & 0 & 0 & 1 & 0 & 0 & 0 & 0 & 1 & 293 \\
\hline & $\mathrm{Zj}$ & 98700 & 71700 & 35700 & 0 & 0 & 98700 & 71700 & 35700 & \\
\hline & $\mathrm{Cj}-\mathrm{Zj}$ & 0 & 0 & 0 & 0 & 0 & -98700 & -71700 & -35700 & \\
\hline
\end{tabular}

Untuk menentukan probabilitas dari setiap alternatif, maka digunakan teorema Bayes seperti pada berikut ini:
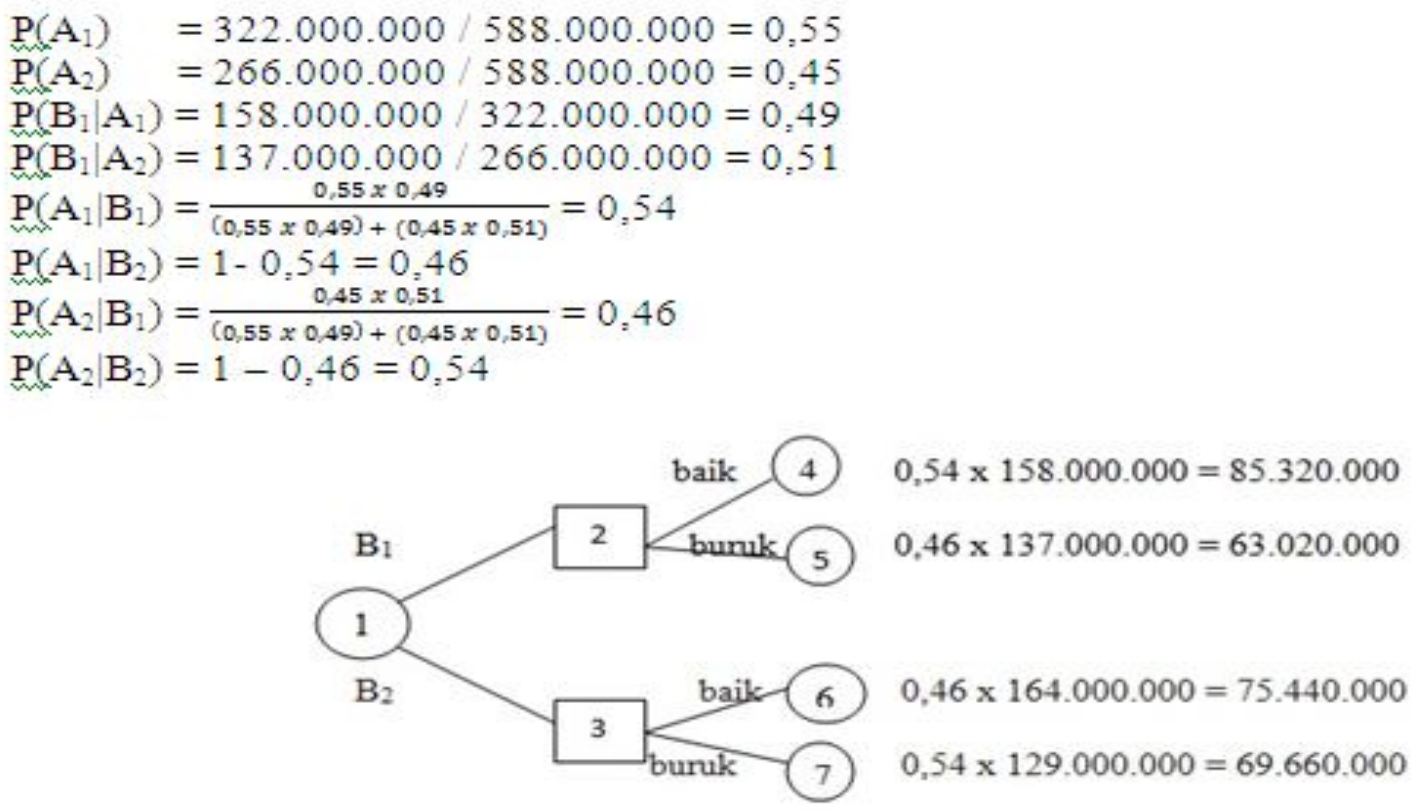

Keterangan:

Nilai harapan $\mathrm{B}_{1}=78.650 .000+63.020 .000=141.670 .000$

Nilai harapan $B_{2}=75.440 .000+69.660 .000=145.100 .000$

Berdasarkan perhitungan, nilai harapan $\mathrm{B}_{2}$ lebih besar daripada $\mathrm{B}_{1}$. Hal ini menunjukkan bahwa keuntungan yang didapatkan perusahaan lebih besar jika memilih alternatif $\mathrm{B}_{2}$. Oleh karena itu, bahwa berdasarkan pohon keputusan, alternatif yang sebaiknya dipilih oleh perusahaan adalah alternatif $\mathrm{B}_{2}$, yaitu meningkatkan kapasitas produksi. 


\section{SIMPULAN}

Berdasarkan hasil analisis data dari PT Primajaya Pantes Garment, dapat disimpulkan bahwa metode peramalan yang paling tepat untuk digunakan perusahaan adalah metode regresi linear dengan nilai MAD dan MSE terkecil, sehingga hasil peramalan dengan metode regresi linear dapat digunakan oleh perusahaan sebagai standar ukuran untuk periode berikutnya. Dengan perhitungan menggunakan metode Linear Programming, laba maksimal yang dapat dicapai perusahaan pada periode berikutnya adalah sebesar Rp157.089.900,00 dengan memproduksi 1065 lembar polo shirt pria, 579 lembar polo shirt wanita, dan 293 lembar polo shirt anak-anak. Selain itu, terdapat slack pada bahan baku kain sebesar 703,6567 $\mathrm{m}^{2}$ dan pada jam kerja tenaga kerja sebesar 4223,6617 jam. Dengan menganalisis 2 alternatif yang dapat menjadi bahan pertimbangan perusahaan dengan menggunakan pohon keputusan, maka dapat disimpulkan bahwa perusahaan sebaiknya memilih alternatif $\mathrm{B}_{2}$, yaitu meningkatkan kapasitas produksi.

\section{DAFTAR PUSTAKA}

Dimyati, T. T. \& Dimyati, A. (2006). Operations Research. Bandung: Sinar Baru Algensindo.

Fariza, A. (2007). Time Series (Deret Berkala), Statistik Ekonomi. Jurusan Teknologi Informasi Politeknik Elektronika Negeri Institut Teknologi Sepuluh Nopember.

Hasibuan. $\quad$ (2011). Diakses $15 \quad$ Juli 2012 dari http://repository.usu.ac.id/bitstream/123456789/24360/3/Chapter\%20II.pdf.

Heizer, J. \& Render, B. (2009). Operations Management (Manajemen Operasi). Buku 1, Edisi 9, Edisi Indonesia. Jakarta: Salemba Empat.

Mulyono, S. (2007). Riset Operasi. Jakarta: Lembaga Penerbit Fakultas Ekonomi Universitas Indonesia.

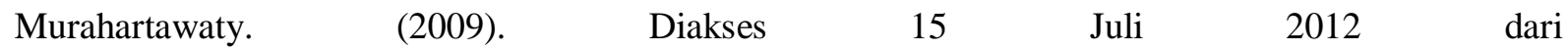
http://if29noltiga.9.forumer.com/index.php?s=1b665dad463ec7e2954e9a7fb5dc80d2\&act=A ttach\&type $=$ post $\& \mathrm{id}=105$.

Murugan, N. \& Manivel, S. (2009). Profit planning of an NGO run enterprise using linear programming approach. Internasional Research Journal of Finance and Economics, 23, $443-454$.

Nugroho, K. W. (2002). Eksentrik Digraf dari Graf Star, Graf Double Star dan Graf Komplit Bipartit. Jember: Jurusan Matematika, Fakultas Matematika dan Ilmu Pengetahuan Alam, Universitas Jember. 